\title{
The Efficiency of a Behavioral Cognitive Group Counseling Program in Reducing Anger Level and Developing Self Concept Among a Sample of Refugee Female Syrian Students in Jordan
}

\author{
Saleh Hassan AL-Daheri ${ }^{1}$ \\ ${ }^{1}$ Educational Sciences College, World Islamic Sciences \&Education University, Amman, Jordan \\ Correspondence: Saleh Hassan AL-Daheri, Educational Sciences College, World Islamic Sciences \&Education \\ University, Amman, Jordan. E-mail: hash_mored@yahoo.com
}

Received: July 6, $2020 \quad$ Accepted: July 20, $2020 \quad$ Online Published: August 31, 2020

doi:10.5539/ass.v16n9p34 URL: https://doi.org/10.5539/ass.v16n9p34

\begin{abstract}
The study aimed at examining the developing efficiency of behavioral cognitive group counseling program in reducing anger and developing self concept. The sample of the study which consisted of 40 refugee female Syrian students in Jordan was assigned into two groups; experimental $(n=20)$ and control $(n=20)$. The program consists of a set of sessions. Two measures were used; Anger Measure and the Psychological one. Results showed statistical significance of the program. The study came up with some recommendations.
\end{abstract}

Keywords: grouping, behavior, cognitive, counseling, training program

\section{Introduction}

Natural disasters have created many incidents and problems to different societies and now the whole world has been surrounded by variety of horrible disasters which human mind cannot tolerate. In different societies, psychological oppression and pressure have appeared as phobia, lack of self-confidence, and low self-esteem, in addition to the increase of emotional anger among most of the people in general (Kendall and others, 1990). All of these disasters led to a set of educational, economic and professional problems. For example, wars in the Arab World especially in Syria forced a big number of Syrians to leave their country. Jordan hosted a big number of these refugees. The Kingdom of Jordan has suffered since 2011 from the sequences of the Syria crises. Jordan hosted around 1.3 million Syrian living in three refugees camps and Zaatari Camp is the biggest. The Syrian students, particularly the female students were exposed to a variety of economic, social, educational and psychological problem and so the role of the students which hosted these students became greater by paying further attention not for just educational issues but also to the social, economic and political issues. At school stage, anger was a common behavior appeared among the students which affected their educational progress and therefore, the study aimed to examine the efficiency of a behavioral cognitive group counseling program in reducing Anger level and developing self concept among this group of refugees.

\subsection{Problem of the Study}

The study's significance stems from the importance of studying the social, educational and psychological problems represented by the Syrian female refugees' anger with low self concept and looking for solutions. The study soak to look for a solution to the problem by answering the following major question: What is the efficiency of a behavioral cognitive group counseling program in reducing Anger level and developing self concept among refugee female Syrian students in Jordan?

\subsection{Questions of the Study}

The study tried to answer the following sub-questions:

Q1: Are there any significant differences between the experimental and control groups at the $(\alpha=0.05)$ on a scale of self-esteem attributed to the program?

Q2: Are there any significant differences between the experimental and control groups at the $(\alpha=0.05)$ on a scale of Anger attributed to the program? 


\subsection{Significance of the Study}

Theoretically, the study stems its significance from the society it addressed. More refugees means the problem becomes more complicated especially with those who have not rehabilitated yet. From the practical point of view, this part of society needs rehabilitation, education, higher degree of adaptation, social and psychological compatibility, and self concept development. Additionally, Ministry of Education can provide much care to this group through the application of this behavioral cognitive group counseling proposed program.

\subsection{Terms of the Study}

1. The cognitive, behavioral and counseling program: is one of the counseling programs that is applied on a group of individuals chosen for the having the same problem (Zahran, 1992). Procedurally, it is a set of counseling methods represented by training counseling sessions that involve activities to reduce anger and develop the self-esteem concept of the Syrian refugees students in Jordan.

2. Self concept: it is the basic component of the personality. And anyone who has low degree of self concept is considered as a negative person who thinks in a negative way (Zahran, 1992; AlGhareeb, 2004). In short, self concept is the personal perceptions formed by the expertise acquired by the environment (Bracka, 2000). Procedurally, it is the degree which the Syrian females get of self concept measures used in the study.

3. Anger: it is an emotional state characterized by Stress, anxiety and psychological disturbance. And the individual may respond to different real situations with anger (Daheri, 2011). Procedurally, anger means the degree which the Syrian refugees got on the Anger Scale used in the study.

4. The female Syrian refugees in Jordan: students who are enrolled in Al-Qadesia Secondary School for females in Jordan.

\subsection{Limits of the Study}

This study is limited to the Syrian students in Al-Qadeisa Secondary School for female students in Jordan. Two specific measures were used; self concept and anger.

\section{Theoretical Background \& Previous Studies}

\subsection{Theoretical Background}

Jordan has faced many social, cultural and technical changes. There was a great widespread of using modern technology as network services and cell phones, in addition to the social and cultural openness. Moreover, there is unemployment problem that greatly affects Jordan socially and economically. Regardless these previous problems, the refugees problem remains the worst. Many studies pointed out that the refugee process causes loss of social and personal identity, family's disintegration, and lack of the appropriate social brining up of the youth. And this is exactly what has happened with the Syrian refugees especially in Jordan that hosted a great number of Syrian refugees in different school stages. And there are many theories that interpret the general behavior of the Syrian refugees whose their real needs were not fulfilled appropriately even if the hosted country (Jordan) provided many of the social and economic life requirements for them. Behaviorists believe that the psychological stress is represented by the reliance on the learning process as a window through which dangerous situations, that the refugees face and cause anger, could be treated. Golden (1998) assured that the behavioral and psychological results of anger and psychological pressures may lead to great anxious but at the same time they could be effectively successful as they help the individual to take critical decisions and strengthen his ability to face any future failure or success. Moreover, the psychological stress teaches the individual how to solve problems from an early age (Daheri, 2005). Anger is an emotional state which a person passes by as a reaction to social and economic problems. Facing these problems and any difficult situations relied heavily on the strength of the individual's personality.

Self concept means the self perceptions that have been created by the expertise that interprets the individual's behavior through the environment. And it is affected by others' evaluation. Identity, from social perspective, is based on the individual's awareness of uniqueness and solidarity with the society's values. In other word, it is a set of operations located in the individual's personality and it is linked with the society's values and it is prepared according to the common cognitive attitudes in the society. Identity versus role-confusion represents the growth problem at the beginning stage of youth according to Erikson Model for social growth. It is clearly that the self concept is the basic thing that starts to grow up during the individual's interaction with the crises including the political and social refugee. During this crisis, the refugee who makes things that do not match his social and political circumstances, starts to understand his identity. In his theory, Pandora stated that identity has three dimensions; behavioral, cognitive and social. Therefore, the behavioral and cognitive treatment should be used to 
evaluate the situation which the Syrian refugees especially the students passed by. It should be stated here that the study' variables; anger and self concept help in identifying many issues that could be treated using the behavioral and cognitive therapy (Lazarus \& Folkman, 1984).

\subsection{Previous Studies}

1. The study of Ahmad and others (1998) entitled by "effect of group behavioral and counseling program in training on social skills, burn-out level and self concept" aimed to examine the efficiency of group behavioral and counseling program in training on social skills, burn-out level and self concept. A sample consisted of 40 students from one of the public schools at Cairo city was chosen and assigned into two groups; experimental and control. Results showed statistical significant in favor of the experimental group.

2. Zuir's study (2000) aimed at examining the efficiency of a behavioral cognitive group counseling program in anger management of teenager students. The sample which consisted of 62 was assigned into groups; experimental and control. The study used Anger Measure to collect data. Results showed statistic significant differences in favor of the experimental group.

3. Al-Khawaldah (2012) conducted a study entitled by "the impact of the Behavioral cognitive program in reducing anger among a sample of the first Secondary students in Jordan". the study aimed to reveal the impact of Behavioral cognitive program in reducing anger. The sample of the study consisted of 50 students of Secondary schools. Results showed that the program was effective in reducing the students' level of anger.

4. Al-moither (2016) conducted a study aimed at reducing the psychological stresses in the social development centers. The sample of the study consisted of 40 participants distributed into experimental and control groups. Measure of psychological stress was used. Results showed lack of significant differences between the pre and post measure in the experimental group in facing the psychological stress. Additionally, results showed the influence of the program in the psychological stress level.

5. In his study (2013), Rajeen soak to identify the reasons of anger. The sample of the study which consisted of 70 male and female students in Chicago, USA was distributed into experimental group $(n=35)$ and control group $(n=35)$. For collecting data, Anger Measure was used. Results revealed statistic significant differences in favor of the experimental group. There was also an improvement in the reduction of students' level of anger, in addition to an increase in the students' psychological compatibility.

6. Zeir's study (1993) aimed to examine the efficiency experimental counseling program in the social skills and in the development of Baghdad University's students' self-concept. The sample of the study consisted of 16 male students and 19 female students. Measures of Self concept and social skills were used. Results revealed differences in favor of the experimental group in the social skills and self-concept measures.

7. Khalaf's study (2015) aimed to examine the effect of cognitive program in reducing the psychological stress among moderate stage's students. The sample of the study which consisted of 40 students was assigned into two groups; experimental (20) and control (20). Results showed statistical significance in favor of the experimental group as there was a positive effect for the program.

\section{Methodology}

\subsection{Procedures of the Study}

The study includes an accurate description of the population and the sample of the study, in addition to the procedures followed by the researcher. Also, the study highlights the study's tools which are Anger and Self-concept Measures. Moreover, the study's design, variables and the statistic methods are mentioned with details.

\subsection{Participants of the Study}

A sample consisted of 40 female students from Al-Qadesia Secondary school for girls for the academic year 2019 was chosen and assigned into two groups; experimental (20) and control (20). The researcher used measures of anger and self-concept.

Table 1. Participants of the study

\begin{tabular}{ccccc}
\hline \multirow{2}{*}{ Group } & \multicolumn{2}{c}{ Self-concept } & \multicolumn{2}{c}{ Anger } \\
\cline { 2 - 5 } & Pre & Post & Pre & Post \\
\hline Experimental & 20 & 20 & 20 & 20 \\
Control & 20 & 20 & 20 & 20 \\
Total & 40 & 40 & 40 & 40 \\
\hline
\end{tabular}




\subsection{Tools of the Study}

Self-Concept Measure consists of four dimensions; self-esteem (7 items), emotional (70 items), taking responsibility (10 items) and cognitive (9 items). Fifth -Lickert scale was adopted: strongly agree (5), agree (4), neutral (3), disagree (2), strongly disagree (1) to correct the students' responses. The measure validity was checked by presenting it to a group of specialized arbitrators in the Jordanian universities whose note were taken into account so the measure's items became 33 items. According to the measure reliability, Cronbac Alpha for internal consistency was used and its value was (85.1).

The researcher adopted Anger Measure which was designed by Slinger (Slinger, 1988) and localized and applied on the Egyptian environment in 1998 by Abdrahamn \& Abdalhameed. Later it was applied on the Jordanian environment in 2012 by Awad. The measure consists of 30 items examining anger. The measure's validity was checked and its apparent validity was noticed. The measure's reliability was also checked through applying it on a Jordanian sample. For the purpose of the study, the measure was presented to a set of specialized arbitrators in the field of psychological counseling in s some Jordanian universities who approved the measure in its original copy. To ensure the measure's reliability, pretest and posttest were applied on a sample consisted of 20 students. Pearson correlation coefficient was $(0.83)$ and the researcher calculated the internal consistency of the measure using Cronbach Alpha which its value was (0.86). These two values proved that the scale was good enough to be adopted in the study.

\subsection{Variables of the Study}

Independent variable: counseling program. Dependent variable: anger and self-concept.

\section{Results}

To examine the efficiency of a behavioral cognitive group counseling program in reducing Anger level and developing self concept among a sample of Syrian refugees female students in Jordan, Means and standard deviations of the refugees students' degree on the Anger and Self-Concept Measures were calculated as it illustrated in Table 2.

Table 2. Means and standard deviations of the refugees students' degree on the Anger and Self-Concept Measures

\begin{tabular}{cccccccc}
\hline \multirow{4}{*}{ Self-concept } & Group & $\mathrm{N}$ & \multicolumn{3}{c}{ Pre } & \multicolumn{2}{c}{ Post } \\
\cline { 2 - 7 } & & & $\mathrm{M}$ & $\mathrm{SD}$ & $\mathrm{M}$ & SD \\
\cline { 2 - 7 } & Control & 20 & 93.11 & 22.3 & 118.86 & 20.71 \\
& Experimental & 20 & 108.84 & 25.32 & 118.12 & 26.18 \\
& Total & 40 & 109.24 & 25.89 & 114.12 & 24.15 \\
\multirow{3}{*}{ Anger } & Control & 20 & 44.17 & 5.56 & 45.86 & 5.76 \\
& experimental & 20 & 46.18 & 7.12 & 30.32 & 5.46 \\
\hline
\end{tabular}

Table 2 showed statistic significant between the experimental and control groups in the pretest and posttest in the sample's degrees on the two measures.

To analyze the dependent variables, MANCOVA was used as it is illustrated in Table 3.

Table 3. Analysis of MANCOVA results of the effect of group variable and the interaction between them in the refugees' level of Anger and Self-Concept

\begin{tabular}{ccccc}
\hline Variable & $\Lambda$ & F & Freedom degree & Sig. \\
\hline Group & 0.16 & 115.2 & 5 & 50000 \\
\hline
\end{tabular}

Table 4. Results of Two-way analysis of variance in the refugees' degrees on the Anger and Self Concept measures among the two groups and interaction between them

\begin{tabular}{|c|c|c|c|c|c|}
\hline Reliability source & Sum of seq. & FD & Means of eq. & $\mathrm{F}$ & Sig. \\
\hline Pre & 870.12 & 1 & 719.57 & 2.65 & 0.15 \\
\hline Group & 176.12 & 1 & 154.15 & 7.76 & 0.30 \\
\hline Error & 647.70 & 45 & 15.34 & & \\
\hline Total & 6446.13 & 70 & & & \\
\hline
\end{tabular}


The previous Table 4 showed statistical significant differences attributed to Group variable as the value of $(\lambda)$ was $0.16 \%$. To identify which of the variables causes these differences, variance was calculated.

Results according to the order of the study's questions:

1) Are there any statistic significant differences at $(\mathrm{A}=0.05)$ between the degrees of the two groups; experimental and control in Self Concept attributed to the counseling program used in the study?

Based on the results shown in table (4), there are statistic significant differences between the experimental and control groups in Self concept with $(\mathrm{F}=7.67)$ at $(\mathrm{a}=0.05)$. And the differences between the adjusted means were in favor of the experimental group with a mean (118.86) compared to the control group with a mean (119.82) as it is illustrated in Table 3. Accordingly, the proposed counseling program has shown an impact in modifying the female refugees students' elf concept in Jordan.

Table 5. Post adjusted Means of the students' degrees in Self-Concept according to Group Variable

\begin{tabular}{cccc}
\hline Group & $\mathrm{N}$ & $\mathrm{M}$ & Standard error \\
\hline Experimental & 20 & 11.46 & 6.50 \\
Control & 20 & 112.10 & 5.42 \\
Total & 40 & 230.98 & 6.20 \\
\hline
\end{tabular}

Table 5 showed lack of statistic significant impact between the experimental and control groups in Self-Concept Measure which indicated lack of differences in the efficiency of the proposed counseling program.

2) Are there statistic significant differences at $(a=0.05)$ between the means of the experimental and control groups in Anger level at Anger level attributed to the counseling group? Results of Table 5, showed statistic significant differences between the experimental and control groups' degrees in Anger Measure as F value was (360.19) at $\mathrm{a}=0.05$.

Anger level was less in the experimental group with adjusted mean (360.19) compared to the Control Group's adjusted mean (29.45). And therefore, it can be concluded that the counseling program has direct impact on the experimental groups by reducing its Anger level.

Table 6. Results of ANOVA

\begin{tabular}{cccccc}
\hline Reliability source & Sum of seq. & F d & M of seq. & F & Sig. \\
\hline Post & 200.60 & 1 & 200.60 & 23.60 & \\
Group & 365.68 & 1 & 3650.68 & 220.5 & \\
Error & 654.6 & 15 & & 16.40 & \\
Total & 44.6 & 59 & & & \\
\hline
\end{tabular}

Table 7. Post adjusted Means of the Syrian student's degrees on Anger Measure according to group variable

\begin{tabular}{cccc}
\hline Groups & $\mathrm{N}$ & $\mathrm{M}$ & Standard error \\
\hline \multirow{2}{*}{ Experimental } & 20 & 27.70 & 0.97 \\
& Total & 30.70 & 0.80 \\
\multirow{2}{*}{ Control } & 20 & 26.65 & 1.0 \\
& Total & 49.18 & 0.80 \\
\hline
\end{tabular}

\section{Discussion \& Conclusion}

The study aimed at investigating the efficiency of a behavioral cognitive group counseling program in reducing Anger level and developing self concept among a sample of refugee female Syrian students in Jordan. Results of the first question showed an improvement in the level of Self Concept of the experimental group compared to the control group. The researcher attributed this improvement to the counseling program which includes variety of techniques as training on self understanding, enhancing positive work and activating the communication with the society through the program's group sessions and the effective techniques of communication as the social role and modeling. Accordingly, the researcher got the opportunity to interact socially with others and have effective discussion. And therefore, the level of the experimental group's Self concept was improved and its behavior was also modified positively which in turn helped in reducing the Anger level and improving self concept. This result agrees with the study of Rajeen,2013 and Dobson \&Dozois, 2010) which showed the positive role of the 
program in improving the level of Self concept ad reducing the anger of Syrian refugees students. Moreover, the results that showed the students' level of psychological compatibility agrees with some of studies' results as Ahmad(1998), Al-Zuir(2000) and Gazda,et al (1997.)

\section{Recommendations}

The study came up with some recommendations as :

1. The necessity to give further opportunities to the Syrian refugees express themselves freely.

2. Applying the program on other different school stages and on different sample of refugees, for example, male refugees.

3. Giving more lectures about disasters and its causes and results as being a refugee.

4. Guiding the trainees in all the psychological, ethical, social, educational and professional fields.

5. Guiding the trainees towards cooperation with the school's psychological counselor to help them in solving their problems through effective activities and work at school.

\section{References}

Abd Rahman, A., \& Abd Alhameed, A. (1998). Constructing cognitive, behavioral and counseling program in reducing the anger of secondary students in Egypt. Dar al-kitab, Cairo.

Ahmad, et al. (1998). Impact of group counseling and behavioral program in training on the Social skills and psychological burnout. Unpublished thesis, Ein Shams University, Cairo, Egypt.

Al -Moeither, M. (2014). Effectiveness of Counseling Program in Reducing Psychological Pressure of the Beneficiaries of Social Development Center in Deriah. Naif Arab University for Security Sciences, Riyadh.

Al-ghareeb, N. A. (2004). Impact Of training program of the social skills in improving self concept, social efficiency and achievement of students with special needs. Unpublished thesis, University of Jordan.

Al-khawaldah, O. (2012). Effect of the Bahvioral cognitive therapy in reducing anger among a sample of first secondary students. Unpublished thesis.

Al-saed, A. M. (2009). Effectiveness of Behavioral Counseling Program in Reducing Psychological Pressures and Burnout of the Secondary Students in Egypt. Journal of Education. Ein Shams University.

Al-Zuir, J. M. (1993). Constructing a behavioral Counseling Program for Skills Training in Reducing Anger and Self Concept of Female Students at Al-Mosel University. Journal of Al-Mosel University, 120.

Awad, A. (2012). A study of the relation between anger and academic achievement of secondary students in Jordan. Zahran for publishing, Amman, Jordan.

Bracha, K. (2000). Guidance \& counseling. New York University Press.

Daheri, S. H. (2005). Counseling psychological science and its theories. Dar Wael for publishing, Jordan.

Daheri, S. H. (2011). Principles of psychological health. Dar Wael for publishing, Jordan.

Daheri, S. H. (2020). Psychological pressure and its theories. Dar Al-Esar Al-elmi, Amman, Jordan.

Dobson, K., \& Dozois, D. (2010). Historical and philosophical bases of the cognitive - behavioral therapies. In K. Dobson (Ed.), Hand book of cognitive - behavioral therapies. New York, NY: Guilford Press.

Gazda, G., Duncan, J., \& Meadows, M. (1997). Counseling and group procedures: Report of a survey. Counselor education and supervision, 6, 305-310.

Golden, O. (1998). Career's guidance. New York: Columbia University Press.

Kendall, P., Reber, M., Mcleer, S., Epps, J., \& Ronan, K. (1990). Cognitive - Behavioral Treatment of Conduct Disordered Children. Cognitive therapy and research, 14(3), 279-297.

Khalf, M. (2015). Effect of Cognitive, Psychological, Behavioral and Counseling Program in Reducing the Level of the Moderate Stage Students' Psychological Pressure. TEACHER Journal, 210. Education College, Bagdad University.

Lazaros, R. (1984). Personality. Dar Al-Shorooq, Cairo, Egypt.

Lazarus, R., \& Folkman, S. (1984). Stress, appraisal and coping. New York, NY: Springer.

Rajeen, E. (2013). Theories of career development. Prentice Hall, Englewood Cilffs, New Jersey.

Slinger, S. (1988). Transition from vocational guidance counseling psychology. University Press. 
Zuir, M. (2000). Impact of Behavioral Counseling Program in Reducing Psychological Pressures and Developing Self Concept of Students at Education College, Sohaj. Journal of Culture and Development. Education College, Sohaj University.

\section{Copyrights}

Copyright for this article is retained by the author(s), with first publication rights granted to the journal.

This is an open-access article distributed under the terms and conditions of the Creative Commons Attribution license (http://creativecommons.org/licenses/by/4.0/). 